„Przekłady Literatur Słowiańskich”. T. 10, cz. 1

ISSN 2353-9763 (wersja elektroniczna)

DOI https://doi.org/10.31261/PLS.2020.10.01.02

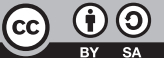

\title{
Minor Literature in the Case of Brina Svit ${ }^{\star}$
}

\section{Literatura mniejsza na przykładzie Briny Svit}

\section{Primož Mlačnik}

iD https://orcid.org/0000-0001-7701-1064

UNIVERSITY OF LJUBLJANA

primoz.mlacnik@fdv.uni-lj.si

Date of application: 12.11.2018 ～Date of acceptance: 10.02.2020

\begin{abstract}
The article draws on the Deleuzoguattarian conceptualisation of minor literature in order to analyse the literature of Brina Svit. The concepts of (de)territorialisation (schizophrenia), minor, and other attributes of minor literature are employed in the comparative analysis of different literary elements of four of Brina Svit's novels. The article outlines the 'line of flight' (defined as deterritorialisation, de-oedipisation, politicalness, and collectiveness) that manifests itself from Svit's novels written in Slovenian to the novels written in French. The literature of Brina Svit is placed in between minor literature and minority literature.
\end{abstract}

KEYWORDS | minor literature, language, politicalness, (de)territorialisation, the novels of Brina Svit

* This article is a part of the project The Production of Meaning and Knowledge in a Time of Crisis: Cultural, Religious and Scientific-Developmental Aspects of Societies in Slovenia, the Balkans, Europe (39176), which is financially supported by the Slovenian Research Agency. 


\section{Introduction}

In the seminal work Kafka: Toward a Minor Literature (1986) [Kafka: Pour une Littérature Mineure, 1975], Gilles Deleuze and Felix Guattari outlined the theory of minor literature through a re-reading of Franz Kafka's literature. Their account of minor literature disregards pre-existing literary categories and genres, while at the same time acknowledges the complex relationship between author and language, desire and writing, and minor and major literature in terms of their power relationship and literary expression. This important and unique literary theory was infused by the following philosophical concepts developed by Deleuze and Guattari in their most important works ${ }^{1}$ : schizophrenia, (de) territorialisation, (de-)Oedipised free-flowing rebellious desire, and the concept of the minor, which has recently been appropriated by several contemporary authors. $^{2}$

Minor literature is defined as literature written by members of the minority in the language of the majority. ${ }^{3}$ This linguistic crossing is often manifested in impoverished language, the detemporalisation and deterritorialisation of the internal construction of the literary work, the persistence of discursive themes of escape and foreignness, the collectiveness and politicalness of the subjective expressions of the main protagonists, and the humanist character and universalizing tendencies that foster intergenerational and intercultural reconciliation and fluidity. However, the character of minor and minor literature is slightly more complicated than the direct application of this theory presupposes.

1 G. Deleuze, F. Guattari, 1983: Anti-Oedipus. Minneapolis, University of Minnesota Press; G. Deleuze, in F. Guattari, 1987: A Thousand Plateaus: Capitalism and Schizophrenia. Minneapolis-London, University of Minnesota.

2 P. Broomans, 2015: The Importance of Literature and Cultural Transfer: Redefining Minority and Migrant Cultures. „Studies on Cultural Transfer \& Transmission” 7, pp. 9-38; J. Cergol, 2014: "Minority" Literature: A Case Study in the Literary Production of the Italian Minority in Slovenia and Croatia and the Slovenian Minority in Italy. "International Journal of Language, Translation and Intercultural Communication" 2, pp. 61-68; J. N. Garcia, 2017: Translation and the Limits of Minority Discourse in the Philippines. „Continuum: Journal of Media and Cultural Studies” 31 (1), pp. 24-32; R. Khan, T. Laurie, 2017: The Concept of Minority for the Study of Culture, „Continuum: Journal of Media and Cultural Studies” 31(1), pp. 92-103; D. Samou, 2014: Narratives of Arab Anglophone Women and the Articulation of a Major Discourse in a Minor Literature. „Interdisciplinary Political and Cultural Journal” 16 (1), pp. 65-81; S. Sarker, 2013: On Remaining Minor in Modernisms: The Future of Women's Literature. „Literature Compass" 10 (1), pp. 8-14; S. Mukherjee, 2016: Videogames as "Minor Literature": Reading Videogame Stories through Paratexts. „Journal of Theory and Criticism” 23, pp. 60-75.

3 G. Deleuze, F. Guattari, 1986. Kafka..., p. 16. 
In order to analyse the literature of Brina Švigelj-Merat, a Slovenian writer who writes under the pseudonym Brina Svit, we will first define and clarify the ambiguities of the concepts employed.

\section{The Multiple Facets of the Minor}

First we must understand that the concept of the minor is relational. The minor only exists as something different from the major, and at the same time in the function of the major. Deleuze and Guattari first elucidated the duality between minor and major in musical terms: "[...] the minor 'mode' gives tonal music a decentred, runaway, fugitive character due to the nature of its intervals and the lesser stability of its chords." In addition, Rimi Khan and Timothy Laurie noticed that a shift to a minor scale in a symphony tends to anticipate the restoration of the major scale, and that listeners (in the case of literature, readers) simultaneously dread the minor states and expect that "wobbly minor refrains melancholic, unsettled, anxious - will segue into steady major statements in order to heighten subsequent feelings of peace and pleasure." Thus the minor always "implies that its essential quality is its difference from the major; that it has a more temporary existence than the major; that it relates to a plurality of minors only by way of a single major [...]." The major is a stable, fixed, and dominating entity, while the minor, which is always under threat of assimilation, is fugitive, temporary, and multiple. The minor strives to achieve "[...] the recognition of heterogeneous identities [...]." In its attempt to liberate itself from the major, being minor implies a constant state of becoming something that is non-identical with the self. Therefore, the structure of the minor is de-territorialised and takes the form of a branched 'line of flight,' "according to which [the multiplicities] change in nature and connects with other multiplicities."

According to Deleuze and Guattari, the schizophrenic character of becoming minor is characterized by unfulfilled and free-flowing desire combined with the liminal and dreary experience of one's own position in social reality. It also designates an involuntary rebellious state or the inability to return to the major. The desire to not be classified in the vocabulary of the major manifests itself in minor literature in several ways. The language of the minor literature "is affected

4 G. Deleuze, F. Guattari, 1987: A Thousand..., p. 95.

5 R. Khan, T. Laurie, 2017: The Concept of Minority..., p. 92.

6 R. Khan, T. Laurie, 2017: The Concept of Minority..., p. 93.

7 S. Sarker, 2013: On Remaining Minor..., p. 97.

8 G. Deleuze, F. Guattari, 1987: A Thousand..., p. 9. 
with a high degree of deterritorialisation," which predominantly means that the

210 language of a minor literary work is subject to a high degree of displacement from the major language. From the point of view of the major language, these displacements are often considered an impoverishment, while from the point of view of the minor, the new language is marked by expressivity, sobriety, flexibility, and intensity. ${ }^{10}$ Because of this complementarity of opposites, Deleuze and Guattari present 'minor' and 'major' as two different usages or functions of the same language. Whereas " $[t]$ he 'major' language is defined by the power of constants, the 'minor' language is defined by the power of variation." ${ }^{11}$ Deleuze and Guattari also define certain conjoined tendencies in 'minor' languages:

an impoverishment, shedding of syntactical and lexical forms; but simultaneously a strange proliferation of shifting effects, a taste for overload and paraphrase. [...] From both sides we see a rejection of reference points, a dissolution of constant form in favour of differences in dynamic. The closer a language gets to this state, the closer it comes not only to a system of musical notation but also to the music itself. ${ }^{12}$

In minor literary works, the expression becomes increasingly autonomous from the content it presupposes. J. Neil Garcia suggests that minor literature is post-representational as "it generates styles and possibilities for its users in contrast to the referential mode of majoritarian literature, which 'expresses' an essentialist image of humanity or identity." ${ }^{13}$ The deterritorialisation of language literally means that the language and the content no longer represent or belong to a specific geographical, usually national, territory. ${ }^{14}$ Khan and Laurie add that instead of the more typical representation or belonging, "minor literature can describe sites of experimentation that allow readers to think outside or beyond existing identity formations organised around the nation-state." ${ }^{15}$

Hence "the second characteristic of minor literatures is that everything in them is political." ${ }^{16}$ This presupposes that the Deleuzoguattarian politicalness has far-reaching implications on the shape of human desire and the social structure. Deleuze and Guattari connect the deterritorialising effects of lan-

9 G. Deleuze, F. Guattari, 1987: A Thousand..., p. 16.

10 G. Deleuze, F. Guattari, 1986: Kafka..., p. 23.

11 G. Deleuze, F. Guattari, 1987: A Thousand..., p. 101.

12 G. Deleuze, F. Guattari, 1987: A Thousand..., p. 104.

13 J. N. Garcia, 2017: Translation..., p. 4.

14 G. Deleuze, F. Guattari, 1986. Kafka..., p. 85; G. Deleuze, F. Guattari, 1987: A Thousand..., p. 63.

15 R. Khan, T. Laurie, 2017: The Concept of Minority..., p. 94.

16 G. Deleuze, F. Guattari, 1986. Kafka..., p. 17. 
guage with the de-oedipisation of human desire. The two authors put forward the view of the Oedipus complex as a Catholic symbol that applies the familiar logic of the holy trinity to commercial, economic, bureaucratic, and juridical social structures. ${ }^{17}$ The Oedipus complex is the prevalent formative structure that tames or restrains desire, and thus disables rebellion against oppressive social structures as its renunciation produces anxiety and guilt as the necessary consequences of the unresolved Oedipus complex. ${ }^{18}$ The Oedipus complex becomes a contradictory yet lucrative idea, employed by traditional Lacanian psychoanalysis in the function of the repression of human desire that is multiple and free flowing. In this account, only a deterritorialised and schizophrenic individual, who is someone only by dint of being someone else, can avoid and escape Oedipal identification ${ }^{19}$ : "the reconciliation of conflict between fathers and sons is not a question of an Oedipal phantasm but of a political program." ${ }^{20}$

Because "[minor literature] does not form canons anchored to Masters [and] [t] he minor is not the achievement of individual heroes [because] it describes multiplicity," ${ }^{21}$ it is political only insofar as it is collective. This is the third characteristic of minor literature. Although "the political futures [of the minor] can be defined in only three ways: integration, assimilation or elimination," ${ }^{, 2}$ it does not directly represent social minorities. The Deleuzoguattarian concept of minor literature has been criticised for being too narrow and for excluding the key characteristics of so-called minority literature: namely, the ontological dimension, interculturalism as an ethical value, pronounced national, linguistic and spatial elements, and historical memory. ${ }^{23}$ In relation to Cergol's critique, I argue that the minor is not merely a subcategory or an equivalent of the minority, but something radically different.

One crucial difference between minor and minority literature is the nature of de-territorialisation in connection with desire. The minor desire is not to be interpreted "by an agent of a dominant social code" ${ }^{24}$ which underlies the linguistic displacements of the minor that reach beyond dialect (one of the many, in this case regional, variations of the minor). In this context, codification is the territorialisation that minor literature attempts to escape. While

17 G. Deleuze, F. Guattari, 1983: Anti-Oedipus..., p. 17.

18 G. Deleuze, F. Guattari, 1983: Anti-Oedipus..., pp. 103-104.

19 G. Deleuze, F. Guattari, 1983: Anti-Oedipus..., p. 81.

20 G. Deleuze, F. Guattari, 1986: Kafka..., p. 17.

21 R. Khan, T. Laurie, 2017: The Concept of Minority..., p. 94.

22 R. Khan, T. Laurie, 2017: The Concept of Minority..., p. 93.

23 J. Cergol, 2014: "Minority" Literature..., p. 61.

24 R. Brinkley, G. Deleuze, F. Guattari, 1983: What is a Minor Literature? „Missisipi Review" 11 (3), p. 13. 
minor literature does not wish to belong to any major literary canon and avoids

212 interpretation through the use of experimental literary techniques, minority literature, as proposed by Cergol (2014), is still caught in the Oedipal phantasm. Namely, it wants to be interpreted and recognised by the major (that is paternal) literary canon. It remains bound to a territory, inclined to narrate the hidden or overlooked histories and struggles of a specific place. The key characteristic of minority literature seems to be the desire to become a part of the majority, while the key characteristic of minor literature is the desire to transform into something else. ${ }^{25}$ Minority literature searches for agents that would interpret and territorialise them within the national geographical and symbolic territories, although they "do not regard the nation-state as their homeland." ${ }^{26}$ Since minorities can be small or large in number, or even constitute an indefinite majority, they "re-create 'nationali-tarian' phenomena that the nation-state had been charged with controlling and quasling." 27 Therefore, minor cannot be automatically equated with minorities, inasmuch as "[d]eterritorialisation [is] not the case for all minor literatures." ${ }^{28}$

Brina Svit, a Slovenian-born writer, has lived in France since 1980. In our analysis, we will analyse the characteristics of two novels that she wrote in the Slovenian language (Con Brio, 1998; Smrt slovenske primadone, 2000 [Death of a Slovenian Prima Donna], and two novels that she originally wrote in French but were later translated into Slovenian (Moreno, 2003; Coco Dias ali Zlata vrata, 2008 [Coco Dias or the Golden Door]). ${ }^{29}$ In this particular case, the Slovenian language performs an ambiguous role. It is the major language that at least hypothetically becomes deterritorialised, or minor, because it is written by a member of the Slovenian majority in the French environment. In other words, the French language, which would usually be considered major in relation to the Slovenian language, becomes the minor language because it is written by a member of a Slovenian minority. Because we are dealing with the translations of the novels written in French, we can follow only the manifestations of deterritorialisation and reterritorialisation in relation to the 'Slovenian plateaus' - the major of the Slovenian language and culture. In the context of minor literature, we will thus

25 S. Mukherjee, 2016: Videogames..., p. 69.

26 J. Cergol, 2014: "Minority" Literature: A Case Study in the Literary Production of the Italian Minority in Slovenia and Croatia and the Slovenian Minority in Italy. „International Journal of Language, Translation and Intercultural Communication” 2, p. 65.

27 G. Deleuze, F. Guattari, 1987: A Thousand..., p. 470.

28 P. Broomans, 2015: The Importance..., p. 26.

29 B. Svit, 1998: Con Brio. Ljubljana, Nova revija; B. Svit, 2000: Smrt slovenske primadone. Ljubljana, Mladinska knjiga; B. Svit, 2003: Moreno. Ljubljana, Cankarjeva založba; B. Svit, 2008: Coco Dias ali Zlata vrata. Ljubljana, Cankarjeva založba. 
view Svit's literature as a whole. In order to trace the possible 'line of flight' and how it might manifest itself, we will conduct a comparative analysis between the two pairs of novels: one pair written in Slovenian and one pair in French (which will be called Slovenian novels and French novels for ease of reference).

\section{Analysing the Traces of the Minor}

To explore the idiosyncratic assumptions regarding minor literature as outlined by Deleuze and Guattari, we raise two specific sets of questions. Which novels by Svit are easier to categorize under the rubric of minor literature rather than minority/majority literature in the Deleuzeoguattarian sense, and how are they represented in relation to her other novels? How does this linguistic shift between minor and major manifest itself? In trying to answer these questions, we will analyse and compare the following categories: the narrator, the fate of the principle protagonists, the linguistic characteristics, and the main conflict. We will identify common patterns, whether the narrators express collective or individual problems, and whether the representation of the protagonists' fate is universal or nation-bound.

First, it is interesting to note that certain observations of language and its sophistication partially confirm Deleuze and Guattaris claim that literature written by the minority is linguistically impoverished. The two Slovenian novels, Con Brio and Death of a Slovenian Prima Donna, feature long, complex sentences, many adjectives, rich descriptions, time-space compression, and the story's development in many different settings. In contrast, Svit's French novels feature simple sentences, extensive dialogue, and the narrator's introspection. It seems as if the gradual deterritorialisation of language is conditioned by the shift from Slovenian to French. Con Brio and Death of a Slovenian Prima Donna are either symbolically or materially bound to the Slovenian territory. In Con Brio, the melancholy female protagonist, Grušenjka, is literally in need of a father(land), and the predominant setting of The Death of a Slovenian Prima Donna is Ljubljana and the Slovenian periphery. The settings of the French novels, Moreno and Coco Dias or the Golden Door, are symbolically and materially distanced from the Slovenian territory. The setting in Moreno is liminal and contemporary, the Santa Maddalena writing residence in Tuscany that hosts a diverse group of international writers and servants for six weeks, while the setting in Coco Dias or the Golden Door is even farther from Slovenian territory: in Paris and Argentina.

Second, it is difficult to classify Svit's literature as consistently minor in the Deleuzean sense solely on the basis of its linguistic traits. Her literature is not 
beyond classification and is certainly not post-representational. Despite this, 214 Svit's language does gradually become deterritorialised. An obvious example of this can be found in The Death of a Slovenian Prima Donna when a gay French journalist is critical of Slovenian cultural habits. At the end of the novel, the main character, a Slovenian woman, dies, which can be understood as the author's symbolic break from Slovenian culture and language. The process of reterritorialisation begins even while the process of deterritorialisation advances. In the novel Moreno, the breaking point of these simultaneous processes occurs when the autobiographical narrator expresses a linguistically-driven identity crisis because of the inability to adequately write in French. Reterritorialisation means to choose another referential culture or language, and to be released from the liminal minor phase, which is the experience of total masterless freedom albeit burdened with anxiety and guilt. Svit's Coco Dias or the Golden Door is already linguistically and territorially bound to the French culture and Paris.

Third, the analysis revealed a number of interesting traits of the narrators in these novels. The narrators of both of Svit's Slovenian novels are French men telling the story of a Slovenian woman. In Con Brio, the narrator is an older writer named R. A. Tibor who falls in love with Grušenjka, a woman of mysterious Slavic origin. The narrator of The Death of a Slovenian Prima Donna is a French journalist who tells the story of a Slovenian opera singer named Lea Kralj. Both of the narrators are troubled by these melancholic women. In contrast, the narrator of Svit's French novels are both women and the characters are autobiographical or semi-autobiographical. Curiously enough, both of these female narrators narrate stories of men. In Moreno, a Slovenian writer, who is clearly Svit's alter ego, describes the experience of residing at a writer's residence in Tuscany and simultaneously narrates the story of a melancholy Moroccan butler. In Coco Dias or the Golden Door, the narrator is also a female writer, less clearly autobiographical, who narrates the story of Coco Dias, an Argentinian man who teaches her how to dance the tango in Paris.

In short, the gender of the narrators changes along with the linguistic shift. In the Slovenian novels, men narrate the stories of melancholy women; in the French novels, women narrate the stories of melancholy men. It appears that the melancholy protagonists are the by-product of the processes of deterritorialisation and reterritorialisation. Certainly, they are connected with the Oedipus or rather the Electra complex, the female version of Oedipus, in which, to put it simply, the female subject fights with her mother and idealises her father. One could interpret the shift of narrators in many ways, but in our theoretical scope, the shift is a sufficient indicator of minor literature, a sign that Svit's literature aims to reconcile intergenerational conflicts between father, mother, and daughter. In addition to this, a different reading of the Oedipus complex 
that could be taken into account was proposed by Shoshana Felman and regards its functional role in the literary narrative that is not limited to the validation of theory but also functions as an element explaining personal history and relating the drama of being a subject. ${ }^{30}$

According to Deleuze and Guattari, intergenerational conflicts, which are as much personal as they are collective, represent a certain site of politicalness. However, rather than positioning Svit's literature as a whole into the project of minor literature, it would be more precise to trace certain minor political subjects. Not everything Svit's protagonists express is collective and political, and therefore we cannot speak of her literary production as exclusively minor. Nevertheless, the linguistic shift and even the author's abandonment of the minor language seems to produce a similar set of problems and minor political subjects as we find in Kafka's literature. Svit establishes politicalness predominantly in the intergenerational conflict, and in the role of the writer and writing.

\section{Politicalness in Svit's Slovenian Novels}

The main conflict in Svit's Slovenian novel Con Brio is presented in the form of a misunderstood social contract between the writer Tibor and Grušenjka, the mysterious Slavic woman. Not long after they meet, they decide to be strangers that love each other and they get married. ${ }^{31}$ They form a marital contract but never define the shared meaning of their love. Throughout the novel the reader perceives Tibor's jealousy and his increasingly desperate attempts to seduce the melancholy and inhibited Grušenjka who does not indulge him. The conflict ends with disenchantment and this confession from Grušenjka:

What comedy, farce, or even tragedy... [...] we both know that we act on the same stage ... Different roles, different games ... Many times we do not choose them ourselves ... I picked you, Tibor [...]. I wanted to be your daughter ... Why can't I choose my own father? I wanted someone to take care of me [...] Let us say that we chose the same game but not the same roles. ${ }^{32}$

Marriage is eradicated but the intergenerational conflict is not completely reconciled. Grušenjka remains inhibited and, as a member of a minority, she

30 S. Felman, 1983: Beyond Oedipus: The Specimen Story of Psychoanalysis. „MLN: Comparative Literature" 98 (5), p. 1029.

31 B. Svit, 1998: Con Brio, p. 24.

32 B. Svit, 1998: Con Brio, p. 156. 
is not capable of completely assimilating into the French fatherland. At the end

216 of the novel it remains unclear whether she will find a new father or not. In Svit's second Slovenian novel The Death of a Slovenian Prima Donna (2000), we encounter the backside of the same problem. The narrator of the story is a gay French journalist, and therefore also a member of a social minority, who follows the Slovenian opera singer Lea Kralj as she tours Europe. Despite her numerous talents as a soprano, pianist, a polyglot, the prima donna's most fascinating talent is her striking performance of death. At the end of each performance, she dies on stage. This bears a striking similarity to The Hunger Artist (1922), a short story written by Franz Kafka in which the main act of the protagonist is starvation. As we become more familiar with Lea Kralj, we discover that she is melancholy by temperament and in search of love. The story moves to Sežana, a peripheral Slovenian town, where Lea lives with her mother with whom she is in deep conflict. The French journalist, an outsider to Slovenian culture, identifies a pathology that is present in Slovenian literary history: namely, the Cankaresque mother, named after the mother of the canonized Slovenian writer Ivan Cankar. A Cankaresque mother, usually a woman without a husband or father figure for her children, is overly sacrificial and unable to let go of her role as a mother even when her children become adults. A Cankaresque mother "loves her imaginary identity more than herself. She is not afraid to be exploited but is afraid to lose her position of suffering. She is prepared to sacrifice everything, except her role as victim,", ${ }^{33}$ which prevents the children from becoming independent individuals.

Lea Kralj's mother is this kind of woman. She makes Lea feel guilty for supposedly abandoning her for a career in a foreign country. She also reproaches her for not taking care of herself. Lea's mother is controlling and supervises everything from Lea's food intake to the clothes she wears. In this context, another Kafkaesque motif comes to mind, which is encapsulated in a remark Kafka once made about his father: "love often wears the face of violence." As a result of the turmoil of everyday events, the relationship between Lea and her mother grows worse and Lea gradually stops eating. She dies of a sudden virus, or at least that is how the journalist has been informed of her death. However, the reader remains sceptical because Lea's mother is an anaesthesiologist, someone with a profession that involves literally putting people to sleep. The question of murder or suicide remains open.

The inhibited and melancholy women in both of Svit's Slovenian novels could be male, and the intergenerational conflictual relationship they represent are also political in a collective sense. According to Slavoj Žižek, the formulation

33 S. Žižek, 1987: Slovenci, ideologija, jezik. Ljubljana, Delavska enotnost, p. 40. 
between fathers, mothers, and their children is central to Slovenian political proclivity to authoritarianism and narcissism. Žižek uses a Lacanian psychoanalytic apparatus to explain the historical inability of Slovenians to publicly rebel against major cultural forces because of their ambivalent relationship towards the universal symbolic law ${ }^{34}$ that in most cases is bound to the domestic household. The ambivalent relationship towards symbolic law is especially prevalent in the era of late-bourgeois society in which the super-ego became maternal. This means that the predominant moral imperative is: "Enjoy!" However, as in Grušenjka's and Lea's case, it is not possible to enjoy, not without first following the paternal superego, which presupposes the imperative: "Do what is right (in order to be capable of true enjoyment)!"

In both of Svit's Slovenian novels, love is the site of political struggle between minor and major languages, and simultaneously represents the conflict between older and younger generations. The protagonists find themselves in a complex web of intertwinement between cultural integration, assimilation, and eradication. On the basis of the main conflicts in Svit's Slovenian novels, which were written when Svit was already living in France, it seems that the processes of deterritorialisation and reterritorialisation are collectively marked by the reconciliation of topical Oedipal problems and the reestablishment of the symbolic law that is represented in a major foreign language.

\section{Politicalness in Svit's French Novels}

In the French novel Moreno, the main task of the autobiographical narrator, who is also the protagonist, is to write. She is residing at the Santa Maddalena writer's residence in Tuscany. However, the narrator has doubts about herself as a writer. She expresses an anxious authorial position similar to what Kafka once expressed in a letter to Max Brod: "The impossibility of not writing, the impossibility of writing in German, the impossibility of writing otherwise."35 The autobiographical narrator presents herself as a minor author that is willing but unable to write in French: "Is my syntax too simple? My vocabulary too plain? Dialogues too colloquial?" In the same utterance in which she expresses her selfdoubt and the anxious feeling of betrayal and melancholic loss that come with the linguistic shift, she compares herself to Nabokov, Cioran, Kundera, Beckett, and Joyce, who were also nostalgic and successful writers. But because she does

34 S. Žižek, 1987: Slovenci..., pp. 105-172.

35 G. Deleuze, F. Guattari, 1986: Kafka..., p. 16. 
not believe in a happy bilingualism, she declares in minor fashion: "I am an ex-communitarian. I reside in language, not in a nation-state. ${ }^{36}$

She affirms another quality, which accompanies the process of minorisation: the privileging of quantification, ${ }^{37}$ which, in her case, is self-imposed. In experiencing her imaginative disabilities, she compares herself with Zadie Smith, a well-established author, who had visited the Santa Maddalena residence prior to Svit. The autobiographical narrator reproaches herself for not writing a sufficient amount of words per day. Zadie Smith wrote more than her. Thus Svit reveals the difficulties of the professional writer: publish or perish.

On the one hand, the plot in Moreno is developed through the narrator's introspection; on the other, it is developed through the description of the life of the butler Mohamed who is dispossessed both materially and symbolically. His wife left him for another man, and he lost his daughter in the divorce. The outcome of these two story arcs is different. The autobiographical protagonist is already well reintegrated into her French life when she receives a call informing her that Mohamed was found unconscious in a ditch. The novel ends on this note, with the suggestion that Mohamed was more of an "ex-communitarian" than she was. His becoming is eradicated, not only because of the nation state of Italy that treats him like a second-hand citizen, but also because of his initial loss to which he could not reconcile. These different outcomes reveal that the experience of being minor and the experience of being a minority do not necessarily overlap. Svit, being minor, tried to identify with minorities. Although she no longer belonged to any language, she was also not capable of belonging to a dispossessed minority. While being minor proves to be a symbolic and existential condition, being a member of a dispossessed minority is more tangible in terms of material conditions. This not only confirms the Deleuzoguattarian view of the minor as a relational concept, but also the concept of minorities as being multiple and intersectional. ${ }^{38}$

Coco Dias or the Golden Door, the last and most recent of Svit's novels in our study, can be read as the continuation of Moreno. Svit has returned to Paris where she is reunited with her husband and children, and almost forgets about Mohamed. Once again, the first person narrator finds herself outlining the life of a man, this time an Argentinian dancer, who is melancholy but to a lesser degree than Mohamed: he is nostalgic. As much as this love story is unusual, experimental, confusing, and even banal, Svit puts the slogan "publish or perish" to use. This is achieved through the metafictional literary strategy of mis-en-

36 B. Svit, 2003: Moreno..., p. 93.

37 R. Khan, T. Laurie, 2017: The Concept of Minority..., p. 93.

38 D. Samou, 2014: Narratives..., p. 69. 
abyme, which allows the writer to use all of her ideas and writings even when they are incompatible. Two cases of mis-en-abyme are present in the novel. The first is the narrator within the narrator. Specifically, the narrative is told by two protagonists, Valerie Nolo, the main protagonist, and Agata, the protagonist of a novel that is being written by Valerie. Another case of mis-en-abyme is present in several long descriptions of the novels, written by Valerie, which are inserted into the novel written by Svit.

It could be argued that in the context of minor literature, Svit was already fully integrated and assimilated into the French language by the time she wrote the novel Coco Dias or the Golden Door. Valerie, the main narrator, is clearly not her representative anymore since she does not experience the self-doubt caused by the linguistic shift from Slovenian to French, and thus is unburdened with history. In this sense, Valerie does not resemble Grušenjka or Lea Kralj. She is more or less happily divorced, uninhibited, and adventurous. In terms of the quantification that accompanies the minor, Svit adapts to the demands of the quantification of a major culture by using metafictional strategies that allow the accumulation of a large number of words.

However, it could also be argued that the process of reterritorialisation is not complete. The schizophrenic wandering between cultural integration, assimilation, and eradication does not result in a fixed identity, and is no longer represented on the level of literary content but rather on the level of literary form, and more precisely, in the appropriation of metafictional narrative techniques. From this standpoint, this novel is the most experimental. It is characterized by the desire not to be interpreted, thus demanding that "[...] the reader becomes a nomad." ${ }^{39}$ Readers are given a similar perplexing impression when reading Coco Dias, the impression, also present in Deleuze's and Guattari's introduction to Kafka's prose - that the text is "a burrow" that allows multiple entries, none of which is privileged. ${ }^{40}$ This means that Coco Dias can be unlocked with different interpretative keys. From this standpoint also, the literary work is minor because it strives to avoid referential cultural frames and classification. Although the quality of the minor cannot depend only on the reader's interpretative skills, this case indicates the expedience of a possible shift of perspective regarding the quality of the minor. The desire not to be interpreted also reveals the contingent nature of the literary work, and the powerlessness of the writer who has lost so many of her cultural assets. In these terms, Coco Dias, as a post-representational work, is symptomatic of the writer's shame for abandoning her minor language while simultaneously not fully adopting the majority language.

39 R. Brinkley et al., 1983: What is a Minor Literature?..., p. 14.

40 R. Brinkley et al., 1983: What is a Minor Literature?..., p. 13. 


\section{Between Minor and Minority Literature}

Instead of determining which of Svit's novels is the most minor, we have discovered certain traces of the minor within the general process of deterritorialisation and the inconsistent 'line of flight.' We have analysed the gradual process of becoming minor through the perspective of the narrator, the main conflict, the fate of the main protagonists, and the variations in language, as well as the various differences between the Slovenian and French novels. The narrator shifts gender, being male in Con Brio and The Death of a Slovenian Prima Donna and becoming female and more schizophrenic in Moreno and Coco Dias or the Golden Door. In terms of the main conflict, the Electra complex is present in the Slovenian novels and absent in the French novels. From a Deleuzeoguattarian perspective, this indicates the resolution of intergenerational conflict and the formation of a new (schizoid) identity. In contrast, Felman's perspective would indicate the disappearance of the Electra complex (as a functional discursive subject) and a linguistic shift that possibly signifies liberation from the infantilising effects of cultural otherness or more precisely, and in keeping with Felman's account of Oedipus of Colone, its acceptance in the writer's own personal narrative, ${ }^{41}$ whose political futures are defined as somewhere between assimilation and integration.

As far as the linguistic variations are concerned, the language is syntactically richer in the Slovenian novels, being slightly impoverished and soberer in Moreno, the first of Svit's French novels, and becoming more polished, innovative, and unconventional in Coco Dias, the second of Svit's French novels. Regarding politicalness, the expression is nation-bound and collective, and more transnational and intercultural in the 'French' novels. Thus, the shift of perspective mentioned in the previous chapter indicates that the minor as a quality of a literary work can be analysed as being relative to the development of the writer's literariness, which brings us to two conclusive lines of argumentation and assumption. First, in these terms, literature is no longer subordinated to theory since it informs theory, ${ }^{42}$ and, second, the quality of the minor does not belong only to the literary work, especially if we consider its misrecognising essence. The minor can be treated as the field between authorship, literary analysts, and readership, which also changes the perspective on the Deleuzeoguattarian politicalness of the minor. In this sense, the minor can be analysed in a wider scope between aesthetics and politics, perhaps in line with Jacques

41 S. Felman, 1983: Beyond Oedipus..., p. 1027.

42 S. Felman, 1977: Literature and Psychoanalysis. The Question of Reading: Otherwise. „Yale French Studies” 55 (56), pp. 5-10. 
Rancière in terms of the sensible effects that are being produced by the elements of minor literature (the displacement of language, etc.) and the commonalities they address and distribute. ${ }^{43}$

This analysis leads us to the conclusion that Svit's literature as a whole can be considered minor because of the linguistic experimentation, the presence and resolution of the Electra complex, the political expression that strives to be collective yet at the same time is not thoroughly universal and deterritorialised. The process of becoming truly minor was abandoned, and was replaced by the process of reterritorialisation in the French environment and language. Svit's literature is also representative of minority literature because her work puts forward interculturalism as a value, represents members of different minorities, and articulates national, linguistic, and spatial elements. However, it belongs more to the language than to the nation because of the absence of collective historical memory. In this sense, it is not a particularly persuasive representative of either minor or minority literature.

In order to attain a more nuanced understanding of Svit's minor literature, it is necessary to read all of her novels, particularly those written in French. This is because minor literature is a relational concept, and we have for the most part entered the discussion from the Slovenian side. Therefore, the linguistic attributes of minor literature - variation and sobriety - remain partially unattainable. The boundaries between minor literature and minority literature remain unclear. Svit belongs to a category in between: well-read by Slovenian readers and also appreciated by the French. ${ }^{44}$

\section{Literature}

Brinkley R., Deleuze G., Guattari F., 1983: What is a Minor Literature? „Missisipi Review” 11 (3), pp. 13-33.

Broomans P., 2015: The Importance of Literature and Cultural Transfer: Redefining Minority and Migrant Cultures. „Studies on Cultural Transfer \& Tranmission" 7, pp. 9-38.

Cergol J., 2014: "Minority" Literature: A Case Study in the Literary Production of the Italian Minority in Slovenia and Croatia and the Slovenian Minority in Italy. „International Journal of Language, Translation and Intercultural Communication" 2, pp. 61-68.

43 J. Ranciere, 2011: The Politics of Aesthetics: The Distribution of the Sensible. LondonNew York, Continuum.

44 J. Osti, 2001: O romanih Brine Svit. „Sodobnost” 65 (11), p. 1491. 
Deleuze G., Guattari F., 1983: Anti-Oedipus. Minneapolis, University of Minnesota Press.

Deleuze G., Guattari F., 1986: Kafka: Toward a Minor Literature. MinneapolisLondon, University of Minnesota Press.

Deleuze G., Guattari F., 1987: A Thousand Plateaus. Minneapolis-London, University of Minnesota.

Felman S., 1977: Literature and Psychoanalysis. The Question of Reading: Otherwise. „Yale French Studies” 55 (56), pp. 5-10.

Felman S., 1983: Beyond Oedipus: The Specimen Story of Psychoanalysis. „MLN: Comparative Literature" 98 (5), pp. 1021-1053.

Garcia J. N., 2017: Translation and the Limits of Minority Discourse in the Philippines. „Continuum: Journal of Media and Cultural Studies” 31 (1), pp. 24-32.

Khan R., Laurie, T., 2017: The Concept of Minority for the Study of Culture, „Continuum: Journal of Media and Cultural Studies" 31(1), pp. 92-103.

Mukherjee S., 2016: Videogames as "Minor Literature": Reading Videogame Stories through Paratexts. „Journal of Theory and Criticism” 23, pp. 60-75.

Osti J., 2001: O romanih Brine Svit. „Sodobnost” 65 (11), pp. 1486-1491.

Ranciere J., 2011: The Politics of Aesthetics: The Distribution of the Sensible. London-New York, Continuum.

Samou D., 2014: Narratives of Arab Anglophone Women and the Articulation of a Major Discourse in a Minor Literature. „Interdisciplinary Political and Cultural Journal” 16 (1), pp. 65-81.

Sarker S., 2013: On Remaining Minor in Modernisms: The Future of Women's Literature. „Literature Compass” 10 (1), pp. 8-14.

Svit B., 1998: Con Brio. Ljubljana, Nova revija.

Svit B., 2000: Smrt slovenske primadone. Ljubljana, Mladinska knjiga.

Svit B., 2003: Moreno. Ljubljana, Cankarjeva založba.

Svit B., 2008: Coco Dias ali Zlata vrata. Ljubljana, Cankarjeva založba.

Žižek S., 1987: Slovenci, ideologija, jezik. Ljubljana, Delavska enotnost.

\section{Primož Mlačnik}

\section{Literatura mniejsza na przykładzie Briny Svit}

STRESZCZENIE | Artykuł przedstawia analizę literatury Briny Svit na podstawie konceptualizacji literatury mniejszej według Deleuze’a i Guattariego. Pojęcia takie jak (de)terytorializacja (schizofrenia), literatura mniejsza, jak i inne wyznaczniki literatury mniejszej zostały zastosowane $\mathrm{w}$ analizie komparatystycznej różnych składników literackich. Artykuł wyznacza trajektorię (definiowaną jako deterytorializacja, deedypalizacja, polityczność i kolektywność), która przejawia się w powieściach Svit napisanych po słoweńsku 
oraz w powieściach napisanych w języku francuskim. Lieratura Briny Svit umiejscawiana jest pomiędzy literaturą mniejszą a literaturą mniejszościową.

SŁOWA KLUCZOWE | literatura mniejsza, język, polityczność, (de)terytorializacja, powieści Briny Svit

\section{Primož Mlačnik}

\section{Manjšinska književnost na primeru Brine Svit}

POVZETEK | Članek se ukvarja $\mathrm{z}$ deleuzovskoguattarijevsko konceptualizacijo manjšinske književnosti $z$ namenom analize književnosti Brine Svit. V primerjalni analizi različnih literarnih elementov $\mathrm{v}$ štirih romanih uporablja koncepte (de)teritorializacije (shizofrenije), manjšinskega, in druge značilnosti manjšinske književnosti. Članek poudari ,linijo bega, ki se manifestira od romanov, ki so bili napisani v slovenskem jeziku, do romanov, ki si bili napisani $v$ francoskem jeziku. Književnost Brine svit umesti med manjšinsko književnost in književnost manjšin.

KLJUČNE BESEDE | manjšinska književnost, jezik, političnost, (de)teritorializacija, romani Brine Svit

PRIMOŽ MLAČNIK | Junior Researcher in the Department of Cultural Studies at the Faculty of Social Sciences at the University of Ljubljana; currently preparing a $\mathrm{PhD}$ dissertation titled Razmerje med melanholijo in modernostjo na primeru književnosti Franza Kafke (The Liaison between Melancholy and Modernity in the Case of Franz Kafka's Literature). His interests include the different interdisciplinary approaches to the phenomenon of melancholy and modernity, culturological and psychoanalytical approaches to literature, and critical cultural theory. He authored the following articles: Izginjanje političnih šal v postsocialistični Sloveniji (co-authored by P. Stanković) (The Disappearing of Political Jokes in Post-socialist Slovenia. „Anthropos: časopis za psihologijo in filozofijo ter za sodelovanje humanističnih ved," 2018, 50 (1/2), pp. 87-105); The Deconstruction of Freud's Theory of Melancholy, „Družboslovne razprave, 2018, 34 (88), pp. 113-131; Kulturistike - kulturološka branja beletristike (Culturistix - Culturological Readings of Belles Lettres, „Slavia Centralis,” 2019, 12 (2), pp. 46-57); Kafka "Shanghai-Ed": Orientalist China in Kafka's Fiction and Kafkaesque Phenomena in China. „European Journal of Interdisciplinary Studies,” 2019, 5 (2), pp. 36-44; he published a collection of short stories Šarm (2017) (Charm, 2017). 